\title{
Cash management practice, SACCO size and Kenya's deposit taking saving and credit co-operatives financial sustainability
}

\author{
Justus Nderitu Maina* ; Richard Muthii Kiai; Teresia Ngina Kyalo
}

School of Business, Karatina University, Karatina, Kenya

*To whom correspondence should be addressed. Email: andyndech@gmail.com

\begin{tabular}{|l|l|l|l|l|}
\hline DOI: & Received: & Revised: & Accepted: & Published: \\
10.22437/ppd.v8i4.10161 & 26.07 .2020 & 17.08 .2020 & 19.08 .2020 & 07.11 .2020 \\
\hline
\end{tabular}

\begin{abstract}
Deposit taking Savings and Credit Co-operatives (SACCO) are solution to social dilemmas like abject poverty, living standards and unemployment. Nevertheless, 14 percent do not maintain sound cash management practices despite SACCOs oversight authority in Kenya offering guidelines and supervision to the enterprises that would assist in maintaining their financial sustainability. This necessitated for the evaluation of the moderating effect of SACCO size on cash management practice and financial sustainability. A descriptive cross-sectional survey design with a positivism philosophical paradigm was adopted. Emailed questionnaire and data collection sheet were used in data collection which registered a 95 percent response rate. A binary logistic regression results established that with presence of a moderator for the predictor sub-variables, the strength of the relationship between variables registered an insignificant change but with introduction of interaction term, the strength of relationship between variables changed. The study concluded that SACCO size portrayed a statistically significant moderating effect on predictor sub-variables and response variable. The study thus recommends that the management need to consider increasing their SACCO sizes through merging, acquiring the non-performing SACCOs or even conducting intensive marketing since large size SACCO have low chances of being financially unsustainable.
\end{abstract}

Keywords: Cash control, Cash planning, Financial self-sufficiency, Liquidity risk management, Total assets

JEL Classifications: G21, G32, G33, L25

\section{INTRODUCTION}

Cash management practice entails managing the cash inflows and outflows in an effort to maintain an optimal cash balance in the organisation at a particular time. Organisations should hold sufficient cash balances but should also evade redundant cash balances (Khan \& Jain, 2007). The level of cash balances held can be attributed to transaction, precautionary or speculative motives (Waweru, 2011). Therefore, an organisation has to evaluate its need for cash keenly so as to avoid shortage or excess cash. Cash is a crucial asset in the finance sector, thus its effective and efficient management is important (Mutesi \& Mulyungi, 2018). Its prudent management contributes to the achievement of financial sustainability of financial institutions like 
Savings and Credit Co-operative Societies (SACCOs) since it will enhance operations continuity (Eton, Uwonda, Mwosi, Ongwel, \& Obote, 2019). Globally, in the post financial crisis of 2007/8, SACCOs have been encouraged to hire professionals in the effort of maintaining suitable cash management practices for their sustainability (Bamidele, Adigun, Folayan, \& Ibrahim, 2018). However, they still recruit unskilled volunteers who are involved in making important financial decisions. This has seen fraudsters misuse SACCOs through diversion of its resources such as cash into personal investments or pyramid schemes, leading to financially unsustainable enterprises (Cuevas \& Buchenau, 2018). Thus, the need for effective and appropriate cash management is due so as to safeguard the enterprise from closure (Muriuki, 2019).

SACCOs are of much importance more so in Africa in its fight against poverty. Their financial sustainability will facilitate reduction of the continent poverty level, which has increased by 48 percent since 2010 (Omilola \& Lerven, 2019). This is because they operate on the assumption that they exist to the foreseeable future to solve social dilemmas like abject poverty, living standards and unemployment. In addition, they are autonomous and independent institutions that need to manage the generated cash effectively for their financial sustainability (Duguma \& Han, 2018). Nevertheless, their cash has been reducing overtime, thus leading to additional borrowing to cater for operational needs (WOCCU, 2014).

In Africa, Kenya has been leading in SACCOs performance and has been awarded for being in the forefront in the continent. It has also improved in the global ranking to the $11^{\text {th }}$ position (WOCCU, 2014). This has been made possible by the highly supervised Deposit Taking Savings and Credit Co-operative Societies (DT-SACCOs) unlike the non-Deposit Taking Savings and Credit Co-operative Societies (Mugo, Muathe, \& Waithaka, 2018). Non-Deposit Taking Savings and Credit Co-operative Societies offer back office services activities and are supervised by the Commissioner for Co-operatives. On the other hand, those that offer front office services activities are licensed and regulated by SACCO Societies Regulatory Authority (SASRA) but they have to be fully registered under the Cooperative Societies Act CAP 490 (FinAccess, 2016).

DT-SACCOs facilitates financial intermediation, financial deepening and financial inclusion to majority of Kenyans particularly in the rural areas (Mumanyi, 2014). They are also essential in solving social dilemmas like abject poverty, living standards and unemployment. Nevertheless, 14 percent do not maintain sound cash management practices (SASRA, 2018). They are characterized by low liquidity ratio which is less than the prescribed 15 percent, poor cash control, inefficient cash plans and have implemented models susceptible to liquidity risks (Matianyi \& Ndirangu, 2019). This exposes DT-SACCOs to economic shocks that can eventually lender them financially unsustainable. Thus, denying 4.97 million members achievement of their common financial, social, and cultural goals through a mutually owned and democratically controlled venture (SASRA, 2019). Despite, SACCOs oversight authority offering guidelines and supervision to the enterprises that would assist in maintaining their financial sustainability there is still a mystery as the DT-SACCOs are still facing liquidity challenges. Members' may end up losing their trust and confidence in them since they lack a lender of last resort and may paralyze the operations leading to financial unsustainability and eventually delicensing of the enterprise (Financial Sector Development Trust [FSD], 2017). Nonetheless, large size DT-SACCOs experience financial sustainability more than the small ones since they are exposed to sufficient resources for conducting effective cash control, cash planning and managing liquidity 
risks as opposed to others (Matianyi \& Ndirangu, 2019). Small sized DT-SACCOs has been experiencing closure of business attributed to cash mismanagement practices (Muriuki, 2019). Thus, a need still exists to carry out the study so as to experience the benefits of a financially sustainable sub-sector. Since if a solution is not sought the subsector will collapse leading to a loss in the economy. Thus, the main aim of the study was to find a solution in reversing this trend.

Many empirical studies existing globally are largely incoherent and have not looked at the moderating effect of SACCO size on cash management practices and financial sustainability of DT-SACCOs. Researchers such as, Abad, Sánchez-Ballesta, \& Yaguie (2017) observed that SACCO size has a significant moderation effect on the response variable. Mutunga \& Owino (2017) observed that firm size has a significant moderating effect on financial performance while Onwonga (2016) indicated that size has no moderating effect between the cash handling practices and financial performance. However, there are no conclusive studies to indicate whether there is a relationship between SACCO size and financial sustainability of DT-SACCOs. Thus, there was need to find out whether SACCO size have a moderating effect on cash management practices and financial sustainability.

\section{LITERATURE REVIEW}

Cash management theory is accredited to the work of Baumol (1952) who acknowledged that there is need for a firm to provide a formal approach for defining an optimum cash balance under certainty. The theory is based on the assumption that the firm's cash needs are known with certainty. There is a tendency of firm's cash imbursement to occur homogeneously over a certain period of time and the opportunity of holding cash is evident and remains constant. Furthermore, a similar transaction cost will be incurred when converting securities into cash (Baumol, 1952).

Cash management is essential for any entity that wishes to prosper financially. Hence a need arises for development of ways of maintaining an optimal cash balance. The theory main aim was to reduce the cost involved in holding cash balances that don't yield return. This cost encompasses opportunity cost of storing idle cash balance and converting marketable securities. A firm should hold sufficient cash balances but should also evade redundant cash balances. Therefore, the firm has to evaluate its need for cash keenly and cash budgets are responsible for stating the cash needs and estimating the payments over a certain period of time so as to avoid shortage or excess cash (Khan \& Jain, 2007).

Matianyi and Ndirangu (2019) carried out a study where cash management theory was tested. It was noted that there are other factors that affects SACCO optimal cash balance apart from return on idle cash holding time and the transaction cost. SACCOs' assets and liabilities are also essential in balancing the cash. The easier a SACCO have access to cash the higher the amount of fund it will hold and hence sufficient cash. Prudent planning of cash flows is achieved by matching maturity of assets against liabilities maturities. However, maturities for assets must be before those of liabilities so as to have cashflow without shortages (Saunders \& Cornett, 2005). Attaining an optimal cash balance is experienced differently in regard to enterprise size and optimal cash balance is highly attained by large enterprise as compared to small enterprises (Ahuja, Dawar, \& Arrawatia, 2016). This may be necessitated by the ability of large DTSACCOs possessing economies of scale merit in sourcing for better expertise in control and planning for cash flows. 
Empirical review concerning the objective of the study was carried out. Wadesango, Tinarwo, Sitcha and Machingambi (2019) conducted a study to find out the impact of cash flow management on financial sustainability of small and medium enterprises in Zimbambwe. A qualitative and quantitative approach of the study was considered in the study with a target population of fifty five participants from small and medium businesses situated in Gweru and Harare. Using the yamane formula and statification a sample of fifty respondents were considered in the in the interviews and questionnaires. Chi square test results established that cash mangement practices exhibited a significant effect on financial sustainability of the small and medium enterprises. On the other hand, the descriptive statistics results indicated that the owners were familiar with cash management practices and internal controls of a business. They kept records of cash inflows and out flows though majority of them did not develop cash budgets in their enterprises which is a major tool of cash controls. Also majority had no bank accounts and it's a good indication of weaknesses in cash management. The good picture was that segration of duties on cash handling was practiced by the enterprises and it is a sign that appropriate cash management was practiced. The study recommended that there is need for the enterprises to adopt effective internal controls, cash controls, cash planning liquidity manangement as the affect fiancial sustainability which is key to the ever changing world. Nevertheless, the study was not based on any theory as no theory was discussed.

A descriptive research design was adopted by Matianyi and Ndirangu (2019) who did a research on influence of cash management practices on financial performance of DT-SACCOs in Kakamega County. The measurements of cash management practices consisted of cash budgets, monthly members contributions and liquidity management policy. Liquidity management theory anchored the study. The study target population comprised of branch manager, operational managers and loan managers of the four SASRA licensed Savings and Credit Co-operative Societies. The sampled population respondend to the self administered questionnaire. Pearson correlation results indicated that cash management practices and financial performance were significant. The study concluded that regular cash budgeting should be carried out to make the Savings and Credit Co-operative Societies liquid. The study recommended that more training is necessary on cash management to all employees of Savings and Credit Co-operative Societies. An enterprise that keeps records of cash inflows and out flows, develops cash budgets and segrates duties on cash handling is an indication that it has better cash management practices (Wadesango, Tinarwo, Sitcha \& Machingambi, 2019). The goal of the firm and financial resources scarcity makes cash management practices most significanct practice in an organisation. It consists of cash budgetting or planning, cash surplus investment and management of cash flows (Eton, Uwonda, Mwosi, Ongwel, \& Obote, 2019).

Sylvie, Mulyungi and Shukla (2018) on their study on cash management practices noted that cash management is a necessity in firm while mismatching between payment timings and cash availability. The study aimed at evaluating the cash management effect on financial sustainability of small and medium enterprises in Rwanda. It was established that cash management has a significant relationship with financial sustainability. In conclusion, the study advocated that there is importance of controlling cash so as to ensure optimal cash that maintains a financially sustainable firm. On recommendations small and medium enterprises need to strengthen avenues for cash collection by advocating for use of mobile money platforms or commercial banks which gives evidence of transaction took place. In addition, there is need for segregation of 
duties in the enterprises so as to create responsibilities. On the other hand, Wickramasinghe and Gunawardane (2017) tested the nexus between liquidity risk management practices and financial sustainability of Sri Lanka quoted companies. Regressed data results established that liquidity risk management practices had a positive significant connection on financial sustainability of quoted firms in Sri Lanka. However, the research design for the study was not indicated and no recommendations were made. The choice of annual reports period was not justified as well as how the study arrived at a sample size of sixty-five and this may not give a true picture of the study variable's relationship. In addition, as guided by the regression model the study was required to carry out a data analysis for each independent variable on the response variable but this was not witnessed. Thus, the study is incomplete.

Abioro (2013), did a study on the impact of cash management on the financial sustainability of manufacturing companies in Nigeria, a study of Cadbury Nigeria Plc. A structured questionnaire was used to collect data and secondary data was collected from the annual financial statement of Cadbury Nigeria Plc from 2002 to 2011. From the correlation analysis results it was concluded that there exist a significant positive relationship between cash management and financial sustainability. Hence, carrying out effective cash management activities would lead to superior financial sustainability of manufacturing companies. However, Anthonia (2014), argued through the impact of cash management on firms' financial sustainability in selected manufacturing firms in Nigeria where an ex-post facto research design was employed. Results from the correlation analysis indicated that cash management was negatively related to financial sustainability of manufacturing firms. Nonetheless, it is not clear how the study arrived at 16 Northern Nigeria flour mills as sample size as there was no target population and sampling design.

\section{METHODS}

The study adopted a descriptive cross-sectional survey design with a positivism philosophical paradigm. Descriptive cross-sectional survey research design was appropriate for this study as it assisted in gaining knowledge of the influence of cash management practices on financial sustainability of DT-SACCOs in Kenya and thus reply the what, how, where and when question of the study. Consequently, the research philosophy was used since the researcher was objective, the research possessed an observable social reality and the results observed was used in generalization of the situation. Moreover, knowledge is achieved through facts gathering that can offer laws basis (Zikmund, Babin, Carr, \& Griffin, 2010).

Five clusters of DT-SACCOs based on original field of membership; the government based DT-SACCOs, teachers based DT-SACCOs, farmers based DTSACCOs, private based DT-SACCOs and community based DT-SACCOs (SASRA, 2017) were used in selecting the sample size. The cluster random sampling resulted to 119 respondents out of which 95 percent responded. The primary quantitative data was collected by use of an emailed questionnaire while secondary data was collected from the audited DT-SACCOs financial statements and SACCO reports. Questions based on cash management practice measures (cash planning, cash control and liquidity risk management) in DT-SACCOs were posed. Respondents were required to indicate the frequency of occurrence of various cash management practices. A Likert scale was used which was from 5 to 1 where 5 was very often, 4 was often, 3 was sometimes, 2 was rarely and 1 was never. The computed Cronbach's Alpha Coefficient of 0.711 attested the reliability of the questionnaire. 
A hierarchical Binary logistic regression model was used to test the moderating effect of SACCO size on cash management practice and financial sustainability as shown in equation 1,2 and 3 .

$$
\begin{aligned}
& \text { Logit }[p]=\beta_{0}+\beta_{1} c p+\beta_{2} c c+\beta_{3} \text { lrm }+\varepsilon \text {. } \\
& \text { Logit }[p]=\beta_{0}+\beta_{1} c p+\beta_{2} c c+\beta_{3} l r m+\beta_{4} S Z+\varepsilon \text {. } \\
& \text { Logit }[p]=\beta_{0}+\beta_{1} c p+\beta_{2} c c+\beta_{3} l r m+\beta_{4} S Z+\beta_{5} c r p * S Z+ \\
& \beta_{6} c c^{*} S Z+\beta_{7} \text { lrm }^{*} S Z+\varepsilon \text {. }
\end{aligned}
$$

Where: $\beta 0$ is a constant; $\beta_{1}, \beta_{2} \beta_{3}, \beta_{4}, \beta_{5} \beta_{6}$ and $\beta_{7}$ are coefficients

$\mathrm{P}$ is the probability that a DT-SACCOs will be financially sustainable

cp.cc and $1 \mathrm{rm}=$ are the predictor variables (cash planning, cash control and liquidity risk management)

$\mathrm{SZ}=$ Sacco size

$\mathrm{cp}^{*} \mathrm{SZ}=$ cash planning $*$ Sacco size

$\mathrm{cc}^{*} \mathrm{SZ}=$ cash control $*$ Sacco size

$1 \mathrm{rm} * \mathrm{SZ}=$ liquidity risk management $*$ Sacco size

Nagelkerke's R-Square change tested the strength of the association between predictor variable and response variable. Wald test was carried out to test the significance for individual predictor variable at 5\% significance level for the P-values.

\section{RESULTS AND DISCUSSIONS}

\section{Cash management practice descriptive results}

Cash management practice was assessed through cash planning, cash control and liquidity risk management parameters. The respondents were expected to indicate the frequency of occurrence of various cash management practices with 5 being the highest frequency and 1, the least frequency. The descriptive results are shown in table 1, revealed that the parameter that had the highest score was on the DT-SACCOs frequency of recoding cash inflows, which had a mean score of 4.88. It was followed by frequency of recording of cash outflows which had a mean score of 4.86 . The frequency of bank reconciliation of the DT-SACCOs had a mean score of 4.31 while frequency of cash expenses payment, cash budget preparations and cash surplus investment had a mean score of 4.40, 4.06 and 3.73 respectively. The frequency of cash surplus occurrence had a moderate mean score of 3.20 while the frequency of cash shortages occurrences received the lowest mean score of 2.37 .

Table 1. Occurrence frequency of cash management practices

\begin{tabular}{lc}
\hline Cash Management Practices & Mean Statistic \\
\hline Cash budget preparations & 4.06 \\
Cash surpluses occurrences & 3.20 \\
Cash shortages occurrences & 2.37 \\
Cash inflows recording & 4.88 \\
Cash outflows recording & 4.86 \\
Cash surplus investment & 3.73 \\
Bank reconciliation & 4.31 \\
Cash expense payment & 4.40 \\
\hline
\end{tabular}

The results from Table 1, indicates that DT-SACCOs maintain proper cash management practice like conducting bank reconciliation, preparing cash budget, recording cash inflows and outflows, settling cash expenses, investing cash surpluses 
and increasing cash surpluses. However, cash shortages were maintained at a low level. The findings were supported by Pandey (2015) who described cash management practice as involving receipts, payments, investment of surpluses and forecasting of cash necessities.

Efficient and effective cash management practice improves DT-SACCOs ability to meet emergency needs and have a better hand in approaching immediate cash offers and investment opportunities that arise, thus maintaining financial sustainability in the short run (Gyebi \& Quain, 2013). Moreover, cash management practice consists of cash budgetting or planning, cash surplus investment and management of cash flows (Eton, Uwonda, Mwosi, Ongwel, \& Obote, 2019).

The results further indicated that only branch managers, finance managers and chief executive officer who were preferred in authorizing the cash transactions of DTSACCOs as stated by 49.6 percent, 40.7 percent and 9.7 percent of the respondents respectively. The results are presented in the Figure 1.

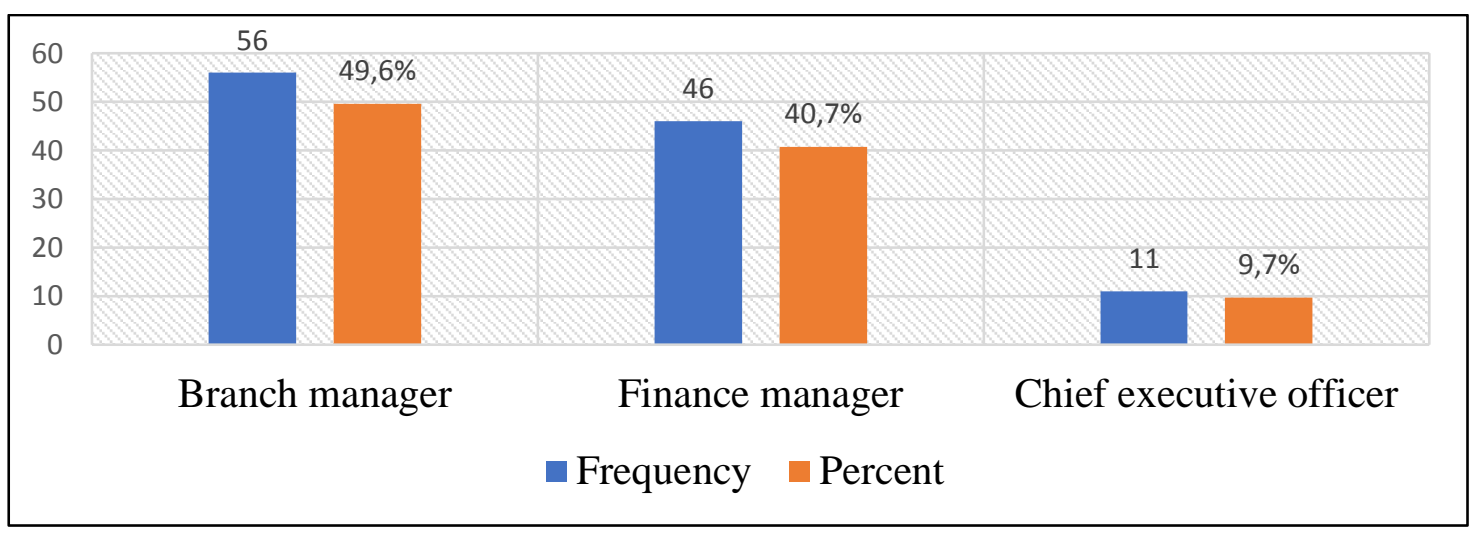

Figure 1. Preferred cash transaction signatories

As shown in Figure 1, the results indicate that branch managers were preferred more than the finance managers and chief executive officer in authorization of cash transaction. This was a sign that the DT-SACCOs were not bureaucratic when handling cash. This could be due to need of having just in time service to their members in the branches. The others who had a preference for finance managers and chief executive officer signatories may be the DT-SACCOs with no branches and they did not have a branch manager. Thus, they preferred finance managers and chief executive officer carrying out the role. This further shows that there is segregation of duties in relation to cash handling.

Further analysis was done on constructs that were being measured by parameters used in the study. To improve construct validity, principle component analysis was used to condense observed variables into factors. Test for multicollinearity was first carried out. The calculated correlation matrix determinant was 0.113 which is more than prescribed value of 0.00001 thus, indicating absence of multicollinearity between variables. Kaiser-Meyer-Olkin and Bartlett's measure of sampling adequacy was used to determine whether factor analysis is appropriate for the study.

Table 2. KMO and Bartlett's test of cash management practices

\begin{tabular}{llr}
\hline Kaiser-Meyer-Olkin Measure of Sampling Adequacy. & 0.589 \\
& Approximated. Chi-Square & 236.125 \\
Bartlett's Test of Sphericity & Df & 36 \\
& Sig. & 0.000 \\
\hline
\end{tabular}


The calculated value as shown in Table 2, for the Kaiser-Meyer-Olkin measure of sampling adequacy was 0.589 while Bartlett's test of Sphericity was at approximated Chi-square of 236.125, 36 degrees of freedom and was highly significant with a $P$ value of 0.000 , hence suitable for factor reduction. Principal components method of extraction and varimax rotation was further conducted. All the components were found to be highly loaded on only three factors as shown in Table 3.

Table 3. Principal Component Analysis Results for Cash Management Practices

\begin{tabular}{c|rrr|rrr}
\hline \multirow{2}{*}{ Component } & \multicolumn{3}{|c|}{ Initial Eigenvalues } & \multicolumn{3}{c}{ Rotation Sums of Squared Loadings } \\
\cline { 2 - 7 } & Total & \% of Variance & Cumulative \% & Total & \% of Variance & Cumulative \% \\
\hline 1 & 2.794 & 31.046 & 31.046 & 2.094 & 23.270 & 23.270 \\
2 & 1.440 & 15.997 & 47.043 & 1.847 & 20.527 & 43.797 \\
3 & 1.168 & 12.978 & 60.022 & 1.460 & 16.224 & 60.022 \\
4 & .923 & 10.258 & 70.280 & & & \\
5 & .805 & 8.949 & 79.229 & & & \\
6 & .788 & 8.754 & 87.983 & & & \\
7 & .486 & 5.403 & 93.386 & & & \\
8 & .364 & 4.043 & 97.429 & & & \\
9 & .231 & 2.571 & 100.000 & & & \\
\hline
\end{tabular}

The components with an Eigen value greater than one were retained (Field, 2013). Three factors (cash control, cash planning and liquidity risk management) were extracted which explained 60.022 percent of the variance of cash management practice. The variables were further used in the logistic regression.

\section{Cash management practice, SACCO size and financial sustainability}

To test the relationship between the variables, the study tested the null hypothesis that there is no significant relationship between cash management practice and financial sustainability of DT-SACCOs. Moderation effect of SACCO size was also tested on independent sub-variables and financial sustainability (Table 4).

Table 4. Hierarchical regression results

\begin{tabular}{|c|c|c|c|c|c|c|c|c|c|}
\hline \multirow[b]{2}{*}{ Predictors } & \multicolumn{3}{|c|}{ Model 1} & \multicolumn{3}{|c|}{ Model 2} & \multicolumn{3}{|c|}{ Model 3} \\
\hline & Beta $^{a}$ & Wald & $\mathrm{P}$ & Beta $^{a}$ & Wald & $\mathrm{P}$ & Beta $^{a}$ & Wald & $\mathrm{P}$ \\
\hline (Constant) & -1.408 & .082 & .775 & 4.142 & .156 & 693 & 25.814 & .020 & .888 \\
\hline $\mathrm{cp}$ & -.011 & .001 & 977 & -.015 & .001 & .970 & -7.412 & 297 & .586 \\
\hline $\mathrm{cc}$ & .611 & 3.925 & .048 & .802 & 3.066 & .080 & 7.371 & 945 & .331 \\
\hline lrm & -.376 & 964 & .326 & -.292 & .537 & 464 & -1.508 & .651 & .420 \\
\hline SZ & & & & -.927 & .354 & .552 & -2.771 & .018 & .894 \\
\hline $\mathrm{cp}^{*} \mathrm{SZ}$ & & & & & & & .811 & .286 & .592 \\
\hline $\mathrm{cc}^{*} \mathrm{SZ}$ & & & & & & & -.735 & .765 & .382 \\
\hline $1 \mathrm{rm} * \mathrm{SZ}$ & & & & & & & .146 & .387 & .534 \\
\hline Nagelkerke $\mathrm{R}^{2}$ & & .209 & & & .215 & & & 237 & \\
\hline
\end{tabular}

As shown in Table 4, the binary logistic regression model 1 for the study; Logit of $($ Financial sustainability $)=-1.408-0.011$ cash planning +0.611 cash control -0.376 liquidity risk management. The $\log$ of odds of a DT-SACCO being financially sustainable was negatively related to cash planning and liquidity risk management while it was positively related to cash control. Thus, an increase in one unit of cash control will lead to an increase in financial sustainability by its coefficient. While, an increase in one unit of cash planning or liquidity risk management lead to a decrease in financial sustainability by its coefficient. The odd ratio Exp (B) indicates the overall effect on response variable of increasing the predictor variables. 
The study established that cash planning was not statistically significant in prediction of DT-SACCOs financial sustainability (Wald statistic value $=0.001$ with a $P$ value of 0.977 and an odd ratio of 0.989). The results supported the research carried out by (Kang'aru \& Tirimba, 2018) while it was in divergent to the study conducted by Sylvie, Mulyungi and Shukla (2018) who established that cash planning has a significant relationship with financial sustainability. On the other hand, cash control was established to be significant in predicting the response variable (Wald statistic value $=3.925$ with 1 degree of freedom, a $P$ value of 0.048 and an odd ratio of 1.843).

The study finding thus, supports the work of Wadesango, Tinarwo, Sitcha and Machingambi (2019) who also found cash control having a significant relationship with financial sustainability. The results further established that liquidity risk management was not statistically significant in response variable prediction (Wald statistic value $=$ 0.964 with 1 degree of freedom, a $\mathrm{P}$ value of 0.326 and an odd ratio of 0.687 ). This is in agreement with the study conducted by (Kigunda, 2018). Nonetheless, the findings were in disagreement with the research carried out by Wickramasinghe and Gunawardane (2017) who concluded that liquidity risk management practices had a positive significant connection on financial sustainability.

To find out the effect of moderator, the study evaluated whether there was change on the strength of association between the variables where Nagelkerke R square was used. The addition of a moderator in Model 2 resulted to an insignificant change in Nagelkerke R square (from 20.9 percent to 21.5 percent). Thus, the moderating effect of SACCO size did not explain significant variation on independent sub-variables and financial sustainability. However, with introduction of interaction term, Nagelkerke R Square changed from 20.9 percent to 23.7 percent. This means that there was significant increase in the variations which was determined by the study variable. Therefore, from the study results it is evident that the relationship improved as interactions effects were introduced in the models.

A continued improvement of the Nagelkerke R Square with the introduction of a moderator and the interactions in the model indicates the significance of the moderator in the study (O'Connell, 2006). The study therefore rejects null hypothesis that, SACCO size is not statistically significant in moderating predictor sub-variables (cash planning, cash control and liquidity risk management) and financial sustainability of DT-SACCOs in Kenya. This in agreement with Abad, Sánchez-Ballesta, and Yagüe (2017) who observed that SACCO size have a significant moderation effect on the response variable. (Mutunga \& Owino, 2017) observed that firm size has a significant moderating effect on response variable no matter the sector they are operating in. In contrary Onwonga (2016) indicated that size has no moderating effect between the independent variable and dependent variable.

\section{CONCLUSION AND RECOMMENDATION}

\section{Conclusion}

The study assessed the effect of cash management practices on financial sustainability of DT-SACCOs In Kenya. Cash management practices was evaluated through cash control, cash planning and liquidity risk management parameters. Based on the study findings DT-SACCOs in Kenya conduct bank reconciliation, prepare cash budget, record cash inflows and outflows, pay cash expenses and invest cash surpluses. Thus, they exercise prudent cash management. Furthermore, SACCOs oversight authority offer them continued guidelines and supervision on prudent cash management practices in an effort to maintain financial sustainable enterprises. However, based on 
results of the analysis, it was concluded that cash control has statistically significant relationship towards financial sustainability while cash planning and liquidity risk management has an insignificant relationship. On the other hand, the moderation effect of SACCO size has a significant moderating effect on cash management practice and financial sustainability.

\section{Recommendations}

Recommendations are offered in an effort to enhance financially sustainability of enterprises in the sub-sector in Kenya. A deposit protection facility set up by the government is needed to cushion DT-SACCOs members in times of failures. On the other hand, a central liquidity facility should be established to act as lender of last resort to DT-SACCOs in case of cash shortages.

DT-SACCOs need to improve their cash management practices such as cash planning, cash control and liquidity risk management so as to maintain a financially sustainable enterprise. This can be done by fully adhering to the recommended liquidity assets to savings deposits ratio of 15 percent while making cash investments. Further, the management need to consider increasing their SACCO sizes through merging, acquiring the non-performing SACCOs or even conducting intensive marketing since large size SACCO have low chances of being financially unsustainable.

\section{REFERENCES}

Abad, D., Sánchez-Ballesta, J. P., \& Yaguie, J. (2017). The Short-term Debt Choice Under Asymmetric Information. Springer, 8, 261-285. doi:doi 10.1007/s13209017-0160-2

Ahuja, N. L., Dawar, V., \& Arrawatia, R. (2016). Corporate Finance. New-Delhi: PHI Learning Private Limited.

Bamidele, M. M., Adigun, O. M., Folayan, O. D., \& Ibrahim, J. (2018). Exploring the Relationship between Financial Management and Performances of Cooperative Organisations in Osun State. Journal of Accounting and Financial Management, 4(4), 10-21. Retrieved from http://www.iiardpub.org

Baumol, W. J. (1952). The transaction demand for cash: An inventory theoretical approach. Quarterly Journal of Economics, 66(4), 545 - 556.

Brown, T. A. (2015). Factor Analysis for Applied Research (2nd ed.). New York-USA: Guilford Press.

Cuevas, C. E., \& Buchenau, J. (2018). Financial Cooperatives: Issues in Regulation, Supervision, and Institutional Strengthening. Washington, DC: World Bank Group.

Duguma, G. J., \& Han, J. (2018). Effect of Deposit Mobilization on the Financial Sustainability of Rural Saving and Credit Cooperatives: Evidence from Ethiopia. Sustainability, 10, 1-23. doi:doi:10.3390/su10103387

Elliot, A. C., \& Woodward, W. A. (2016). IBM SPSS by Example: A Practical Guide to Statistical Data Analysis (2nd ed.). California-United State of America: SAGE Publication Inc.

Eton, M., Uwonda, G., Mwosi, F., Ongwel, B. P., \& Obote, D. (2019). Cash Management and Financial Performance of Business Firms in Northern Uganda a Case of Lira District. The International Journal of Business Management and Technology, 3(4), 115-125. Retrieved from http://www.theijbmt.com/archive/ 0928/2005457400.pdf

Field, A. P. (2000). Discovering Statistics Using SPSS (2nd ed.). London: Sage.

FinAccess. (2016). 2016 FinAccess Household Survey. Nairobi. 
Gyebi, F., \& Quain, S. (2013). Internal control on cash collection. A case of the electricity company of Ghana ltd, Accra East region. International Journal of Business and Social Science, 4(9), 217-233.

Hosmer, D. W., Lemeshow, S., \& Sturdivant, R. (2013). Applied Logistic Regression. New Jersey: John Wiley \& Sons Inc.

Kang'aru, P. N., \& Tirimba, I. (2018). Effect of Financial Planning Practices on the Financial Performance of Non Profit Making Health Organizations in Kiambu County, Kenya. International Journal of Scientific and Research Publications, 8(5), 599-623. Retrieved from http://dx.doi.org/10.29322/IJSRP.8.5.2018.p7778

Khan, M. Y., \& Jain, P. K. (2007). Financial Management: Text, Problems and Cases (5th ed.). New Delhi: Tata McGraw-Hill Publishing Company Limited.

Kigunda, S. N. (2018). Influence of Liquidity Risk Management Practices on Financial Performance of Licensed Deposit Taking SACCOS in Nairobi. Nairobi: KCA University.

Koech, G. M. (2015). The Effect of Budgetary Controls on Financial Performance of Manufacturing Companies in Kenya. Nairobi: Doctoral Dissertation, School of Business, University of Nairobi.

Matianyi, B. J., \& Ndirangu, A. W. (2019). Influence of Cash Management Practicces on Financial Performance of Deposit taking Saccos in Kakamega County. The Strategic Journal of Business \& Change Management, 6(2), 1994-2005. Retrieved from http://www.strategicjournals.com

Mugo, D. M., Muathe, S. M., \& Waithaka, S. T. (2018). Effect of Mobile Communication Services on Performance of Saccos in Kenya. European Scientific Journal, 14(30), 46-62. Retrieved from http://dx.doi.org/10.19044/ esj.2018.v14n30p46

Muriuki, P. (2019). Promoting Financial Inclusion : How Credit Unions are bringing Financial Inclusion to Marginalised Communities. Washington, DC: World Council of Credit Unions.

Mutesi, A., \& Mulyungi, P. (2018). Effect of Cash Management on the Financial Performance of Co-operative Banks in Rwanda: A Case of igma CSS. Invention Journal of Research Technology in Engineering \& Management, 2(5), 88-98. Retrieved from http://www.ijrtem.com

Mutunga, D., \& Owino, E. (2017). Moderating Role of Firm size on the relationship between Micro Factors and Financial Performance of Manufacturing Firms in Kenya. Journal of Finance, 1(1), 14-27.

Njeru, D.M., Njeru, A., Member, F., \& Ondabu, I.T. (2015). Effect of Cash Management on Financial Performance of Deposit Taking SACCOs in Mount Kenya Region. International Journal of Scientific and Research Publications, 5(2).

O'Connell, A. A. (2006). Logistic Regression Models for Ordinal Response Variables. California-USA: SAGE Publication Inc.

Omilola, B., \& Lerven, F. (2019). Accelerating Poverty and Hunger Reduction in Africa: Progress and Policy Prescriptions. New York: UNDP.

Onwonga, M. M. (2016). Effect of Cash Hangling Practices on Financial Performance of Commercial Banks in Kenya. Nairobi: United States International UniversityAfrica. Retrieved from http://erepo.usiu.ac.ke:8080/xmlui/bitstream/handle/ 11732/3487/MAKAU\%20STEPHEN\%20MATHUKU\%20MBA\%202017.pdf?se quence $=1$

Pandey, I. M. (2015). Financial Management (11 ed.). New Delhi -India: Vikas Publishing House PVT ltd. 
Reddy, O. S., Likassa, H. T., \& Asefa, L. (2015). Binary Logistic Regression Analysis in Assessing and Identifying Factors that Influence the Use of Family Planning: The Case of Ambo Town, Ethiopia. International Journal of Modern Chemistry and Applied Science, 2(2), 108-120. Retrieved from http://www.ijcasonline.com/

SASRA. (2016). The SACCO supervision annual report. Nairobi-Kenya: SASRA: The SACCO Societies Regulatory Authority.

SASRA. (2017). The SACCO Supervision Annual Report, 2017. Nairobi: SASRA.

SASRA. (2018). The SACCO Supervision Annual Report,2018. Nairobi: SACCO Societies Regulatory Authority (SASRA).

SASRA. (2019). The SACCO Subsector Demographics Study Report, 2019. Nairobi: SACCO Societies Regulatory Authority (SASRA).

Saunders, A., \& Cornett, M. M. (2005). Financial Markets and Institutions: An Introduction to a Risk Management Approach (3rd ed.). New Delhi: Mcgraw-Hill.

Sebhatu, K. t. (2012). Management of Savings and Credit Cooperatives from the Perspective of Outreach and Sustainability: Evidence from Southern Tigrai of Ethiopia. Research Journal of Finance and Accounting, 2(7), 10-24. Retrieved from https://www.researchgate.net/publication/268364043

Sylvie, N., Mulyungi, P., \& Shukla, J. (2018). Effect of Cash Management Practices on Finanncial Performance of Small Medium Enterprises in Rwanda: Case Study of SMEs in Kicukiro District. International Journal of Management and Commerce Innovations, 6(1), 940-949. Retrieved from http://www.researchpublish.

Wadesango, N., Tinarwo, N., Sitcha, L., \& Machingambi, S. (2019). The Impact of Cash Flow Management on the Profitability and Sustainability of Small to Medium Sized Enterprises. International Journal of Entrepreneurship, 23(3). Retrieved from https://www.abacademies.org/journals/month-september-year2019-vol-23-issue-3-journal-ije-past-issue.html

Wanjala, S. N. (2015). Effect of Cash Management Practices on the Growth of MatatuSaccos in Kimilili Sub-County, Bungoma County, Kenya. The International Journal Of Business \& Management, 3(1), 77-89. Retrieved from http://www.theijbm.com/

Waweru, K. M. (2011). An investigation into the cash balance management challenges in saving and credit cooperative societies in Nakuru County, Kenya. Journal of Research in International Business and Management, 1(5), 130-135. Retrieved from http://www.interesjournals.org/JRIBM

Wickramasinghe, M. B., \& Gunawardane, K. (2017). Cash Flow Risk Management Practices on Sustainable Financial Performance in Sri Lanka. International Journal of Arts and Commerce, 6(8), 57-69. Retrieved from http://www.ijac.org.uk

Yang, K., \& Miller, G. J. (2008). Handbook of Research Methods in Public Administration. New York : CRC Press.

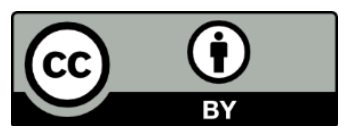

(C) 2020 by the authors. Licensee JPPD, Indonesia. This article is an open-access article distributed under the terms and conditions of the Creative Commons Attribution (CC BY) license (http://creativecommons.org/licenses/by/4.0/). 